\title{
TAX COMPETITION WITH FORMULA APPORTIONMENT: THE INTERACTION BETWEEN TAX BASE AND SHARING MECHANISM
}

\author{
MARTIN KOLMAR \\ ANDREAS WAGENER
}

CESIFO WORKING PAPER NO. 2097

CATEGORY 1: PUBLIC FinANCE

SEPTEMBER 2007

Presented at CESifo Area Conference on Public Sector Economics, April 2007

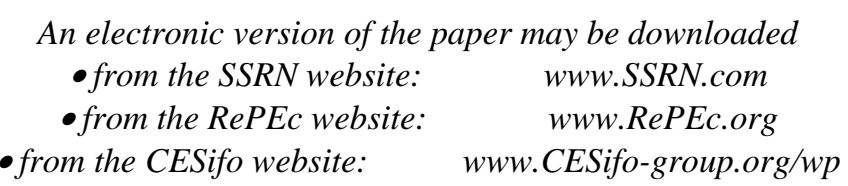




\title{
TAX COMPETITION WITH FORMULA APPORTIONMENT: THE INTERACTION BETWEEN TAX BASE AND SHARING MECHANISM
}

\begin{abstract}
The EU Commission is advocating a common consolidated tax base for the corporate income tax, accompanied by a revenue sharing mechanism based on formula apportionment. We analyse tax competition in such a regime, focussing on the interaction between the definition of the tax base and the apportionment method. Tax competition leads to suboptimally low tax rates if and only if the investment elasticity of the tax base is lower than the investment elasticity of the apportionment factor. For any apportionment method a change in the definition of the tax base can turn a race-to-the-bottom in tax competition into a race-overthe-top.

JEL Code: H77, H25, F23.
\end{abstract}

Keywords: tax competition, formular apportionment, corporate income tax.

\author{
Martin Kolmar \\ FEW-HSG \\ University of St. Gallen \\ Varnbüelstr. 14 \\ 9000 St. Gallen \\ Switzerland \\ martin.kolmar@unisg.ch
}

\author{
Andreas Wagener \\ Institute of Social Policy \\ University of Hanover \\ Königsworther Platz 1 \\ 30167 Hanover \\ Germany \\ wagener@sopo.uni-hannover.de
}




\section{Introduction}

The current practice of corporate income taxation for multinational firms within the European Union (EU) suffers from substantial shortcomings: distortions in factor allocations, high administrative and compliance costs, tax avoidance through cross-border profit shifting and transfer pricing, incentives for thin capitalisation, etc. To a large extent, these shortcomings originate from the co-existence of 27 different and mutually inconsistent tax systems and the requirement to set up a separate tax accounting for every country where a multinational operates. Therefore a comprehensive tax reform that would allow multinational enterprises to operate with a single, common and consolidated tax base for their EU-wide businesses has become a top issue in the tax arena of the EU (European Commission, 2001, 2003, 2006; Devereux, 2004; Sørensen, 2004; Weiner, 2006). In 2004, the European Commission installed a working group to undertake progress work on the definition of the common tax base; a proposal for a directive should be released before the end of $2008 .^{1}$

Consolidation of all activities of a multinational corporation to a single tax base raises the question of how to share this tax base and the attenting tax revenues among the participating member states. While such sharing could be carried out at the macro level (Mintz, 2004), micro-approaches that allocate tax revenues in a company-wise manner to the participating states dominate the discussion and are also preferred by the European Commission (European Commission, 2006; Weiner, 2006). Most attention has so far been devoted to formula apportionment (FA), the mechanism practiced between US states or Canadian provinces (Hellerstein and McLure, 2004).

With FA, a corporation's tax base is shared among the participating countries according to a formula that uses one or several apportionment factors. Each factor measures (or proxies) in a different way the fraction of the overall business activities that a firm runs in

\footnotetext{
${ }^{1}$ Apart from being uniform and consolidated, the new tax base should also be simpler and broader than the existing ones. The process of deliberations is documented at http://ec.europa.eu/taxation_customs/taxation/company_tax/common_tax_base/index_en.htm.
} 
the respective country. The tax revenues that accrue to a country out of a multinational's operations within its jurisdiction are given by the product of that country's statutory tax rate, the value of the apportionment factor according to the formula, and the multinational's total (= EU-wide or worldwide) taxable profits, calculated according to the common consolidated tax base. A politically and fiscally important component of a FA arrangement is that the participating countries keep full autonomy over their tax rates. Only the tax base is uniform; tax rates are left to the national governments' discretion.

On the European level, work on the design of the mechanism to share the consolidated tax base among member states has not yet been started. Rather, the European Commission expressly views technical issues concerning the sharing mechanism as "relatively independent" (e.g., European Commission, 2006, p. 7) of those involved in the definition of the consolidated tax base. As we argue in this paper, such a view is inappropriate. Discussions about the design of a common tax base and the mechanism to share it ought not to be separated.

Specifically, we elaborate on the interaction between the definition of the tax base and the apportionment method in tax competition games. The actual or potential emergence of tax competition, especially with profit taxes, has figured prominently in the political and scientific debate on taxation in the EU. Switching to a FA system with a consolidated tax base will not only change incentive structure for companies (investment, workforce etc.) but also for national governments that use their tax policies (i.e., set their tax rates) strategically. The status quo of EU corporate income taxation is based on separate accounting. Here, tax competition is generally viewed to be of the much-feared race-tothe-bottom type. ${ }^{2}$ Tax competition under FA taxation may look quite different. Several authors (e.g., Wellisch, 2002; Sørensen, 2003; Pethig and Wagener, 2007) pointed out that with a consolidated tax base the apportionment method decisively shapes strategic incentives in tax policies. In particular, the sharing rule may determine whether tax

\footnotetext{
${ }^{2}$ Separate accounting encourages firms to shift taxable profits into low-tax countries. This implies a positive fiscal cross-border externality of corporate income taxes and, thus, triggers a race-to-the-bottom in tax competition (Nielsen et al., 2004).
} 
competition is of the "race-to-the-bottom" type (too low tax rates) or of the "race-overthe-top" type (inefficiently high tax rates). In this paper, we demonstrate that the same phenomenon can occur when, for a given apportionment method, different definitions of the tax base apply. Moreover, given a formula for tax base apportionment, a change in the tax base definition can turn a race-to-the-bottom into a race-over-the-top.

Generally, the type of tax competition is shaped by the sign of fiscal externalities, i.e., by the spillover effects that one government's tax activities generates on the objectives of other governments. Positive fiscal externalities lead to inefficiently low Nash equilibrium tax rates in tax competition, negative ones to inefficiently high tax rates (where cooperative behaviour serves as the benchmark for efficiency). With FA taxation, fiscal externalities arise through two channels: tax changes in one country affect the other government both via the shares of tax revenues allocated to the countries and via their impact on the joint tax base. Underlying both fiscal externalities are changes in the behaviour of firms (say, with regard to investment). Either of these fiscal externalities can be positive or negative, implying, first, that tax competition may come as a race-to-the-bottom as well as a race-over-the top and, second, that it is the interplay between apportionment factor and tax base definition that has to be scrutinized when analyzing tax competition.

As the main result of this paper, we show that the Nash equilibrium tax rate of a tax competition game under FA taxation is too high [low], relative to the cooperative one, if and only if the consolidated tax base responds absolutely more [less] elastically to changes in investment than does the apportionment factor. ${ }^{3}$

This elasticity condition is shon to have an interesting and simple equivalent in terms of capital flows: FA tax competition leads to inefficiently high [low] tax rates if a tax change in one country leads to changes in foreign and domestic investment behaviour that go into the same direction [into opposite directions]. I.e., if tax changes under FA either reduce or increase both foreign and domestic investment, a negative fiscal externality prevails

\footnotetext{
${ }^{3}$ Importantly, it is elasticities with respect to investment that matter - and not elasticities with respect to tax rates.
} 
(race-over-the-top); otherwise, a positive externality emerges (race-to-the-bottom).

Since the elasticities of tax base and apportionment factor are economically and mathematically independently, the two fiscal externalities can be cleanly disentangled. Roughly this implies, however, that for any given formula for tax base sharing a change in the definition of the tax base could turn a race to the bottom into a race over the top.

The rest of this paper is organized as follows: Section 2 presents the model of a tax competition game with FA. Section 3 characterizes the possible outcomes of FA tax competition games. Section 4 exemplifies these findings for two prominent apportionment methods. Section 5 concludes. All proofs are in the Appendix.

\section{The Model}

\subsection{General description}

Inspired by a framework developed in Nielsen et al. (2004) and Sørensen (2003), we consider a common market that comprises two identical, small open economies, labelled $A$ and $B$. The two countries (plan to) operate with a commonly agreed base for taxes on consolidated profits that is to be shared according to an formula-based apportionment method. We consider a single representative multinational corporation that operates in the common market. It has to decide on how much capital $K_{i}$ to invest in country $i=A, B$. Investment decisions determine economic profits. We assume that the economic profit $\pi_{i}$ realizable in either country can be clearly identified and unambiguously attributed to investment decisions in that country only: $\pi_{i}=\pi\left(K_{i}\right)$ where $\pi(\cdot): \mathbb{R}_{+} \rightarrow \mathbb{R}$ is a pseudoconcave function that satisfies $\pi(0) \leq 0, \pi^{\prime}(0)=+\infty$, and that takes strictly positive values (at least) over some interval of the real line. Pre-tax economic profits of the multinational total to

$$
\Pi_{g}\left(K_{A}, K_{B}\right)=\pi\left(K_{A}\right)+\pi\left(K_{B}\right)
$$

The multinational firm has to pay profit taxes to the governments of both countries 
where it operates. Countries $A$ and $B$ share a common rule of how to calculate (national and consolidated) taxable profits. Specifically, that common rule defines the profit tax base in country $i$ (such that the multinational perceives it) as a function $\phi\left(K_{i}\right): \mathbb{R}_{+} \rightarrow \mathbb{R}$ which depends on investments in $i$. The consolidated tax base amounts to ${ }^{4}$

$$
\Phi\left(K_{A}, K_{B}\right)=\phi\left(K_{A}\right)+\phi\left(K_{B}\right)
$$

Differences between taxable profits $\phi\left(K_{i}\right)$ and economic profits $\pi\left(K_{i}\right)$ may result from non-deductible expenses, tax-depreciation rules, tax exemptions, valuation rules, the inor exclusion of unrealised incomes and many other details. Divergence of $\phi$ from $\pi$ results in non-neutrality of profit taxation (i.e., is responsible for tax-induced distortions in investment behaviour). ${ }^{5}$

\section{$2.2 \quad$ FA Taxation and Profit Maximization}

An apportionment method assigns fractions of the common consolidated tax base $\Phi$ to the countries $A$ and $B$. These fractions are thought to reflect how the firm allocates its activities across the two countries. In our simple model these activities are represented by $K_{A}$ and $K_{B}$, but in practice some other factors (payroll, sales, etc.) may be included in the formula. We denote by

$$
\alpha: \mathbb{R}_{+}^{2} \rightarrow[0,1], \quad \alpha=\alpha\left(K_{A}, K_{B}\right)
$$

\footnotetext{
${ }^{4}$ We assume that measuring assets $K_{i}$ for the purpose of taxation and FA is unproblematic. In practice, this may be quite difficult since intangible assets become ever more important for the operation of firms. Moreover, we abstract from any tax-motivated transactions within the multinational (like internal shipments at fabricated transfer prices). This reflects the idea that such manoeuvres are no longer necessary under a common tax base.

${ }^{5}$ This statement needs to be qualified in dynamic contexts where divergence of $\phi$ and $\psi$ does not necessarily lead to non-neutral taxation (think, e.g., of business income $\pi$ in the Schanz-Haig-Simons definition together with cash flows as the tax base $\psi$ ).
} 
the share of tax revenues that is assigned to country $A$. Country $B$ 's share then equals $\beta:=1-\alpha\left(K_{A}, K_{B}\right) .{ }^{6}$ We impose the following plausible restrictions on $\alpha$ :

$$
\begin{aligned}
\alpha\left(K_{A}, K_{B}\right)+\alpha\left(K_{B}, K_{A}\right) & =1, \\
\alpha\left(0, K_{B}\right) & =0, \\
\alpha_{K_{A}}\left(K_{A}, K_{B}\right)> & 0>\alpha_{K_{B}}\left(K_{A}, K_{B}\right)
\end{aligned}
$$

for all values $K_{A}, K_{B}>0 ; \alpha_{K_{i}}:=\partial \alpha / \partial K_{i}$. Property (1a) ensures an equal treatment of countries; relabelling the countries would not change the value of the apportionment factor. This permits to calculate country $B$ 's share simply as $\beta\left(K_{A}, K_{B}\right)=\alpha\left(K_{B}, K_{A}\right)$. Moreover, if the multinational runs two equally large firms in $A$ and $B$ then the tax base is shared equally between $A$ and $B: \alpha(K, K)=0.5$ for all $K>0$. By properties (1a) and (1b), if the firm does not operate in a country, this means a zero tax share for that country. Property (1c) conveys that an increase in the multinational's activities in a country increases that country's tax share. ${ }^{7}$

Tax revenues in $A$ and $B$ amount to

$$
T_{A}=t_{A} \cdot \alpha \cdot \Phi \quad \text { and } \quad T_{B}=t_{B} \cdot(1-\alpha) \cdot \Phi
$$

and the net profits of the multinational company are given by:

$$
\Pi_{n}\left(K_{A}, K_{B}\right)=\Pi_{g}\left(K_{A}, K_{B}\right)-\left(t_{A} \alpha+t_{B}(1-\alpha)\right) \cdot \Phi
$$

The FOCs for optimal investment choices reflect that the effective profit tax rate is variable from the firm's perspective via the apportionment method:

$$
\frac{\partial \Pi_{n}}{\partial K_{i}}=\pi^{\prime}\left(K_{i}\right)+\left(t_{A}-t_{B}\right) \cdot \frac{\partial \alpha}{\partial K_{i}} \cdot \Phi-\left(\alpha t_{A}+(1-\alpha) t_{B}\right) \cdot \phi^{\prime}\left(K_{i}\right)=0 \quad(i=A, B) .
$$

\footnotetext{
${ }^{6}$ This seems natural in the context of the EU where member states agree on a common formula ex ante. When, as in the U.S., states can freely choose their own formulas, fractions need not add up to unity. In fact, the choice of fractions may be a matter of strategic considerations or bilateral agreement (see Anand and Sansing, 2000; Wellisch, 2004).

${ }^{7}$ If two apportionment methods each satisfy properties (1a) to (1c), then so do their convex combinations. A case in point here is the so-called Massachusetts formula, applied in the US, which uses payroll, property and sales shares in equal proportions.
} 
The multinational's responses to tax changes under a FA are quite complex. To simplify the analysis, we will throughout assume that the identical countries also levy identical tax rates in the initial situation: $t_{A}=t_{B}=t$. This then implies identical investment levels in both countries $\left(K_{A}=K_{B}=K\right)$ and $\alpha=1 / 2$. For comparative statics exercises, we can confine ourselves to changes of $t_{A}$. Variations in $t_{B}$ follow one-by-one according to the pattern:

$$
\frac{\partial K_{B}}{\partial t_{B}}=\frac{\partial K_{A}}{\partial t_{A}} \quad \text { and } \quad \frac{\partial K_{A}}{\partial t_{B}}=\frac{\partial K_{B}}{\partial t_{A}}
$$

for all $t_{A}=t_{B}=t$. In a symmetric setting, implicit differentiation of (4) yields the following effects of a tax change in $A$ on investments:

$$
\begin{aligned}
\frac{\partial K_{A}(t, t)}{\partial t_{A}} & =\frac{\alpha \phi^{\prime}(K)+\alpha_{K_{A}} \Phi}{\pi^{\prime \prime}(K)-t \phi^{\prime \prime}(K)} \\
\frac{\partial K_{B}(t, t)}{\partial t_{A}} & =\frac{\alpha \phi^{\prime}(K)+\alpha_{K_{B}} \Phi}{\pi^{\prime \prime}(K)-t \phi^{\prime \prime}(K)} .
\end{aligned}
$$

Observe that the expressions in the denominators of (6a) and (6b) are negative from the second-order conditions. Hence, a tax increase in country $i$ drives capital out of that country, $\partial K_{i}(t, t) / \partial t_{i}<0$, if (but not only if) $\phi^{\prime}(K)$ and, therefore from (4), also $\pi^{\prime}(K)$ is positive, i.e., if higher investment still lead to an increase in (taxable) profits in $i$. However, (6a) also entails the possibility that higher taxes attract capital to a country (namely, if $\phi^{\prime}(K)$ and, thus, $\pi^{\prime}(K)$ are sufficiently negative). This may, e.g., happen if the tax base definition involves generous allowances (see Section 4).

From (6b), the impact of domestic tax increases on investment abroad is unclear whenever $\phi^{\prime}(K)>0$; otherwise capital will be attracted to the foreign country. However, for all FA methods with property (1a) a tax increase in any of the two countries changes total investment by the same amount; i.e. independently of the function $\alpha,{ }^{8}$

$$
\frac{\partial\left(K_{A}+K_{B}\right)}{\partial t_{i}}=\frac{\phi^{\prime}(K)}{\pi^{\prime \prime}(K)-t \phi^{\prime \prime}(K)} \quad \text { for } i=A, B
$$

A tax increase in one country changes the effective tax rate and thereby changes the marginal return to investment everywhere. Hence, total investment $K_{A}+K_{B}$ is affected.

\footnotetext{
${ }^{8}$ Add up (6a) and (6b) and observe that $\alpha_{K_{A}}+\alpha_{K_{B}}=0$ under symmetry.
} 
Moreover, the country where the tax increase occurs becomes less [more] attractive for hosting investments with positive [negative] marginal profits, relative to the foreign country. Hence, marginally profit-increasing domestic investments will always be cut back upon domestic tax increases. However, in the foreign country two opposing effects are at work for marginally profit-increasing investments: the overall increase in the effective tax rate versus the increase in relative attractiveness as a host for investment. That leaves it generally unclear whether investment increases or declines there.

\subsection{Cooperative Solution and Tax Competition}

We assume that governments aim at maximizing tax revenues, using the statutory tax rates $t_{A}$ and $t^{B}$ as their policy instruments. We adopt this Leviathan assumption - which is common in recent studies on tax competition under FA - to make our point as swiftly as possible; qualitatively similar (but more complex) effects as the ones derived below can emerge for different objective functions too.

Tax revenues in each country depend, via the firm's optimal choices, on both tax rates: $T_{i}=T_{i}\left(t_{A}, t_{B}\right)$. Governments can cooperate (joint revenue maximization) or not (tax competition).

The cooperative solution is the pair of tax rates $\left(t_{A}^{*}, t_{B}^{*}\right)$ that maximizes joint tax revenues $T_{A}+T_{B}$, given the taxation method and the common definition of the tax base. We will henceforth assume that a unique symmetric cooperative solution (with tax rate $t^{*}$ ) always exists.

Nash equilibria of a non-cooperative tax competition game are pairs of tax rates $\left(t_{A}^{N}, t_{B}^{N}\right)$ such that $T_{i}\left(t_{i}^{N}, t_{j}^{N}\right)=\max _{t_{i}} T_{i}\left(t_{i}, t_{j}^{N}\right)$. We only consider unique, symmetric and interior Nash equilibria which are determined by the following FOCs:

$$
\frac{\partial T_{A}\left(t^{N}, t^{N}\right)}{\partial t_{A}}=\frac{\partial T_{B}\left(t^{N}, t^{N}\right)}{\partial t_{B}}=0 .
$$

Given our assumption that the cooperative solution is unique, we obtain that a Nash equilibrium tax rate $t^{N}$ is too high [too low], relative to $t^{*}$, if a negative [positive] fiscal 
externality prevails:

$$
\frac{\partial T_{i}\left(t^{N}, t^{N}\right)}{\partial t_{j}} \leq 0 \quad \text { for } i \neq j \Longleftrightarrow \quad t^{N} \geq t^{*}
$$

Due to symmetry, this condition will be simultaneously met or violated in both countries.

\section{Tax Competition with FA}

For tax competition under FA we get the following result:

Proposition 1 With non-cooperative profit taxation under FA, a positive [negative] fiscal externality prevails in a symmetric situation whenever a tax increase in one country affects investments in the two countries in different [identical] directions::

$$
\operatorname{sgn} \frac{\partial T_{i}\left(t^{N}, t^{N}\right)}{\partial t_{j}}=-\operatorname{sgn}\left(\frac{\partial K_{i}^{F A}\left(t^{N}, t^{N}\right)}{\partial t_{j}} \cdot \frac{\partial K_{j}^{F A}\left(t^{N}, t^{N}\right)}{\partial t_{j}}\right) .
$$

Fiscal externalities under FA can, thus, be characterized via investment responses at home and abroad. The probably most relevant case (and the one on which the literature has so far focussed) occurs when domestic tax increases reduce domestic investment (i.e., $\left.\partial K_{j} / \partial t_{j}<0\right)$. Then (9) states that if capital investment abroad also declines upon domestic tax increases, the foreign government will lose revenues upon a domestic tax increase, whereas if foreign investment increases, the foreign government will gain additional tax revenues. While this sounds all too natural, it should be stressed that a tax change in one country affects the other country's tax revenues in multiple ways: via a change in the common profit tax base $\Phi$ and via a change in the formula share $\alpha$, and each of these effects contains variations in both $K_{A}$ and $K_{B}$. Proposition 1 then states that all these changes can be condensed in the sign of the cross-border effects on investment.

As an immediate implication of Proposition 1 and (8), Nash equilibrium tax rates are too high [too low], relative to the cooperative solution, whenever a tax increase in one 
country affects investment in both countries in different [identical] directions. We can, however, be even more specific:

Proposition 2 The tax rate in the symmetric Nash equilibrium of a tax competition game under FA is too high [low] relative to the cooperative one if and only if the common consolidated tax base $\Phi$ responds absolutely more [less] elastically to changes in investment than the apportionment factor $\alpha$ :

$$
t^{N} \geq t^{*} \Longleftrightarrow\left|\frac{\partial \Phi(K, K)}{\partial K_{A}} \cdot \frac{K}{\Phi(K, K)}\right| \geq \frac{\partial \alpha(K, K)}{\partial K_{A}} \cdot \frac{K}{\alpha(K, K)}
$$

where $K=K\left(t^{N}, t^{N}\right)$.

From (10), the nature of tax competition under consolidated taxation with FA can only be determined from analyzing both the tax base and the apportionment method. It is not enough to look at one of the components only. Proposition 2 offers a precise separation of the apportionment- and the tax base-effects. Relative to the maximum of a (joint) Laffer curve, tax competition will more likely result in a "race to the bottom" the more elastic the tax base and in a "race over the top" the more elastic the apportionment factor is with respect to investment.

It is non-trivial that elasticities with respect to investment matter in Proposition 2. Recalling that tax revenues in country $B$ are given by $T^{B}=t_{B} \cdot(1-\alpha) \cdot \Phi$, a positive [negative] fiscal externality will prevail if the elasticity of the common consolidated tax base $\Phi$ with respect to the tax rate $t_{A}$ in country $A$ exceeds [falls short of] the corresponding elasticity of the apportionment factor $1-\alpha$. Proposition 2 shows that these tax elasticities translate one-by-one into elasticities with respect to $K_{A}$.

By the definition of $\Phi$, the tax-base elasticity can also be written as $\phi^{\prime}(K) K /[2 \phi(K)]$. Moreover, $\alpha(K, K)=0.5$ by assumption. Hence, (10) leads to the following condition which will prove helpful later:

$$
t^{N} \geq t^{*} \Longleftrightarrow\left|\frac{\phi^{\prime}(K) K}{\phi(K)}\right| \geq 4 K \frac{\partial \alpha(K, K)}{\partial K_{A}} .
$$

at $K=K\left(t^{N}, t^{N}\right)$. Observe that both (10) and (11) are local conditions: they need only be valid in the Nash equilibrium but not globally. 


\section{Two Examples}

In this section we exemplify that the nature of the tax competition game under FA in fact is determined by the definitions of both tax base and apportionment factor. We consider two prominent apportionment methods (each of whom satisfies properties (1a) to (1c)): property-share and sales-share apportionment. Both methods are applied in the U.S. or in Canada.

\subsection{Apportionment with Property Shares}

With property-share apportionment, taxable profits are assigned to countries according to the fraction of the firm's total capital invested there:

$$
\alpha\left(K_{A}, K_{B}\right)=\frac{K_{A}}{K_{A}+K_{B}}
$$

For this method, $K \cdot \frac{\partial \alpha(K, K)}{\partial K_{A}}=1 / 4$. Applying (11) we thus obtain:

$$
t^{N}<t^{*} \Longleftrightarrow\left|\phi^{\prime}(K)\right|<\phi(K) / K \quad \text { where } K=K\left(t^{N}, t^{N}\right) .
$$

Property-share apportionment is the most widely studied sharing method in tax competition games under FA. All studies so far consider the following set-up: The multinational firm earns revenues $R\left(K_{i}\right)$ from its operations in country $i$ and incurs costs $C\left(K_{i}\right)$, both written here as functions of investment in $i$. Both revenues and variable costs are zero in the absence of investment $(R(0)=C(0)=0)$. Revenues are assumed to be strictly concave in $K_{i}$ with $R^{\prime}(0)$ sufficiently large,${ }^{9}$ and costs are assumed to be increasing and convex in $K_{i}$. Capital costs may reflect costs of finance or economic depreciation of the capital stock etc. Profits $\pi\left(K_{i}\right)=R\left(K_{i}\right)-C\left(K_{i}\right)$ are strictly concave then. Taxable profits are modelled as $\phi\left(K_{i}\right)=R\left(K_{i}\right)-\gamma \cdot C\left(K_{i}\right)$ where $\gamma \geq 0$ measures the degree of tax-deductibility of costs.

\footnotetext{
${ }^{9}$ E.g., the firm has concave Inada-type production function $x=f\left(K_{i}\right)$ and faces an inverse-demand function $p=p(x)$. Then revenues $R\left(K_{i}\right)=p\left(f\left(K_{i}\right)\right) f\left(K_{i}\right)$ are concave in $K_{i}$ as long as $p(x)$ is not "too convex" (which will in particular be the case when a competitive output market with $p(x)=\bar{p}$ is assumed.
} 
If at most the full amount of costs is tax-deductible (i.e., if $\gamma \in[0,1]$ ), the FOC (4) for profit-maximization in a symmetric situation always involves $\phi^{\prime}(K) \geq 0$ (with equality iff $\gamma=1)$. By the concavity of $\phi$ and $\phi(0)=0$, the RHS of (13) is satisfied for all $K$. Consequently, inefficiently low tax rates $\left(t^{N}<t^{*}\right)$ will emerge from the FA tax competition game.

However, Sørensen $(2003,2004)$ argued that FA based on property shares may well lead to inoptimally high tax rates. This can be easily verified in the present set-up by allowing for $\gamma>1$, i.e., by assuming that firms can tax-deduct more than their true expenses (due, say, to generous write-off provisions etc.). Then $\phi^{\prime}(K)<0$ will hold in the firm's profit maximum (again see (4)). Thus, concavity of $\phi$ does not suffice to make the RHS of (13) hold true. Moreover, it is easy to construct examples such that tax competition under property-share apportionment leads to excessively high tax rates. One such example is provided in the Appendix.

Inefficiently high tax rates can emerge under property apportionment even without assuming excessively generous cost deductibility. Assume, e.g., that costs have a fixed and a variable component: $C(K)=\bar{C}+\tilde{C}(K)$ with $\bar{C}>0$ and $\tilde{C}(0)=0$. Suppose that $\gamma \leq 1$, such that $\phi^{\prime}(K)>0$ in a firm's optimum. The RHS of condition (13) then reads as:

$$
K\left(R^{\prime}(K)-\gamma \tilde{C}^{\prime}(K)\right)<R(K)-\gamma(\bar{C}+\tilde{C}(K))
$$

It is straightforward to show that this condition is always satisfied for a linear cost function (i.e., $\tilde{C}(K)=c \cdot K)$. Hence, inefficiently low tax rates will emerge in tax competition. However, for non-linear $\tilde{C}(K)$ it is equally straightforward to construct examples such that the condition above is violated.

\subsection{Apportionment with Sales Shares}

A further prominent FA method is apportionment according to sales (or output) shares. Denoting the multinational's revenues from its operations in country $i$ by $R_{i}$, profits are 
assigned according to the formula $\alpha=R_{A} /\left(R_{A}+R_{B}\right)$. Assuming that revenues earned in $i$ depend, apart from some other factors which are exogenous to our model, on investment in $i$, i.e., $R_{i}=R\left(K_{i}\right)$ with $R(0)=0$, we obtain

$$
\alpha\left(K_{A}, K_{B}\right)=\frac{R\left(K_{A}\right)}{R\left(K_{A}\right)+R\left(K_{B}\right)} .
$$

In symmetric situations, $4 \cdot K \cdot \partial \alpha(K, K) / \partial K_{A}=R^{\prime}(K) K / R(K)$. Whenever revenues are concave in investment, this is smaller than one. From (11), tax competition under sales-share apportionment will surely lead to a race-over-the-top whenever the elasticity of the tax base with respect to $K$ exceeds one. For not-so-elastic tax bases, the situation is less clear.

Consider the set-up of the previous example with profits $\pi=R(K)-C(K)$ and tax bases $\phi=R(K)-\gamma C(K)$. Assume first that there are no fixed costs $(C(0)=0)$. From (11), $t^{N} \geq t^{*}$ will then hold for $\gamma<1$ if and only if $\left.R^{\prime}(K) / R(K)<C^{\prime}(K) / C(K)\right)$. However, $C^{\prime}(K)=R^{\prime}(K)(1-t) /(1-\gamma t)$ from the FOC (4). Replacing $C^{\prime}(K)$ and eliminating $R^{\prime}(K)$, the RHS of $(11)$ becomes $(1-t) R(K)-(1-\gamma t) C(K)>0$ which is equivalent to positive after-tax profits. Reasonably assuming this, tax competition with sales-share apportionment always leads to inefficiently low tax rates.

For $\gamma>1$ (which implies that $\phi^{\prime}=R^{\prime}-\gamma C^{\prime}<0$ ), the RHS of (11) reads as $2 / \gamma \leq$ $C / R-C^{\prime} / R^{\prime}$. By again replacing $C^{\prime}$ from the FOC and then rewriting expression one sees that this is incompatible with non-negative profits - hence, suboptimally high tax rates emerge from tax competition.

Linear cost functions $C(K)=\bar{C}+c \cdot K$ (with $c, \bar{C}>0$ ) also lend themselves to an instructive example. Analysing (11) it is straightforward to demonstrate that tax rates in a symmetric Nash equilibrium will be suboptimally low if costs are fully deductible in the tax base (i.e., for $\gamma=1$ ) and inefficiently high if they are not at all deductible (i.e., for $\gamma=0$ ). By continuity, there exists an interior value such that tax competition generates the cooperative solution. Slightly perturbing that value, however, will lead to drastic changes in the nature of the tax competition game. Interpreting the share $\gamma$ of capital costs that is not tax-deductible as a measure for the "broadness" of the tax base, 
we find that the broader [narrower] the tax base the less likely tax competition will be of the "race-over-the-top" ["race-to-the-bottom"] type.

The case of a linear cost function highlights that indeed both the apportionment method and the tax base definition matter: With property-share apportionment a race-to-thebottom emerges for all $\gamma \in(0,1)$ (see the previous section) while for the same definition of the tax base races-over-the-top are possible with sales-share apportionment.

\section{Concluding Remarks}

Corporate income tax competition with FA taxation is shaped both by the definition of the tax base and by the apportionment method. While the impact of the sharing rule has been analysed in a number of studies, the role of the tax base has so far been negelected in the literature. Moreover, as this paper shows, it is the interplay between the two features that determines FA tax competition.

These insights have a couple of policy implications for the discussion in the European Union on how to adopt a consolidated tax base with formula-based tax base sharing:

First, switching from separate accounting to FA taxation might alter the nature of the tax competition game drastically, turning the customary race-to-the-bottom in corporate tax rates under separate accounting upside down under formula apportionment.

Second, the prospect of ending up on the deccreasing part of the joint Laffer-curve for corporate income tax revenues as a result of a non-cooperative tax-competition game is quite disturbing. As all reforms of corporate income taxation take place under the political restriction that member states keep their tax rate autonomy, tax competition per se can probably not be precluded. When designing the tax base and the sharing mechanism, the European Commission should be careful to avoid the "wrong" side of the Laffer curve.

Third, separating the discussions on the definition of the tax base for the corporate income tax and on the apportionment method for tax revenues is unwise, at least if the incentives for strategic national tax policies are among the criteria that count for the 
choice of a new tax method in the EU. Due to their interplay in tax competition, sharing rule and tax base should be decided on as a package.

\section{Acknowledgements}

The authors would like to thank Joann Martens-Weiner, Marcel Gérard, Paolo Panteghini, and seminar participants in Copenhagen, Vienna and Munich for helpful comments and discussions. The usual disclaimer applies.

\section{Appendix}

\section{Proof of Proposition 1}

As $\alpha_{K_{A}}(K, K)=-\alpha_{K_{B}}(K, K)$ for all symmetric investment levels $K>0$, we use (2), (6a) and (6b) to calculate:

$$
\begin{aligned}
& \frac{\partial T_{A}(t, t)}{\partial t_{B}}= t_{A} \cdot\left[\left(\alpha_{K_{A}} \frac{\partial K_{A}}{\partial t_{B}}+\alpha_{K_{B}} \frac{\partial K_{B}}{\partial t_{B}}\right) \cdot \Phi\right. \\
&\left.\quad+\alpha \cdot\left(\frac{\partial K_{A}}{\partial t_{B}} \cdot \phi^{\prime}\left(K_{A}\right)+\frac{\partial K_{B}}{\partial t_{B}} \cdot \phi^{\prime}\left(K_{B}\right)\right)\right] \\
&=t_{A} \cdot\left[\alpha_{K_{A}} \cdot \frac{\partial\left(K_{A}-K_{B}\right)}{\partial t_{B}} \cdot \Phi+\alpha \cdot \phi^{\prime}(K) \cdot \frac{\partial\left(K_{A}+K_{B}\right)}{\partial t_{B}}\right] \\
&=\frac{t}{\pi^{\prime \prime}(K)-t \phi^{\prime \prime}(K)} \cdot\left[-\alpha_{K_{A}} \cdot \Phi^{2} \cdot\left(\alpha_{K_{A}}-\alpha_{K_{B}}\right)+2 \alpha^{2} \phi^{\prime}(K)^{2}\right] \\
&=\frac{2 t}{\pi^{\prime \prime}(K)-t \phi^{\prime \prime}(K)} \cdot\left[-\alpha_{K_{A}}^{2} \Phi^{2}+\alpha^{2} \phi^{\prime}(K)^{2}\right] \\
&=\frac{2 t}{\pi^{\prime \prime}(K)-t \phi^{\prime \prime}(K)} \cdot\left[\alpha \phi^{\prime}(K)-\alpha_{K_{A}} \Phi\right] \cdot\left[\alpha \phi^{\prime}(K)+\alpha_{K_{A}} \Phi\right] .
\end{aligned}
$$

Using (6a) and (6b), the sign of (14) equals

$$
-\operatorname{sgn}\left(\left[\alpha \phi^{\prime}(K)-\alpha_{K_{A}} \Phi\right] \cdot\left[\alpha \phi^{\prime}(K)+\alpha_{K_{A}} \Phi\right]\right)=-\operatorname{sgn}\left(\frac{\partial K_{B}}{\partial t_{A}} \cdot \frac{\partial K_{A}}{\partial t_{A}}\right)
$$

which is equal in sign to $\left(\partial K_{A} / \partial t_{B}\right)\left(\partial K_{B} / \partial t_{B}\right)$ due to symmetry. 


\section{Proof of Proposition 2}

Consider a symmetric situation: $t_{A}=t_{B}$ and, thus, $K_{A}=K_{B}=K$. From (14),

$$
\begin{aligned}
\frac{\partial T_{A}(t, t)}{\partial t_{B}} \leq 0 & \Longleftrightarrow-\alpha_{K_{A}}^{2}(K, K) \Phi^{2}(K, K)+\alpha^{2}(K, K) \phi^{\prime}(K)^{2} \geq 0 \\
& \Longleftrightarrow\left(\frac{\phi^{\prime}(K)}{\Phi(K, K)}\right)^{2} \geq\left(\frac{\alpha_{K_{A}}(K, K)}{\alpha(K, K)}\right)^{2} \\
& \Longleftrightarrow\left|\frac{\phi^{\prime}(K)}{\Phi(K, K)}\right| \geq \frac{\alpha_{K_{A}}(K, K)}{\alpha(K, K)} \\
& \Longleftrightarrow\left|K \cdot \frac{\partial \Phi(K, K) / \partial K_{A}}{\Phi(K, K)}\right| \geq K \cdot \frac{\alpha_{K_{A}}(K, K)}{\alpha(K, K)} .
\end{aligned}
$$

Here we observed that $\alpha, \alpha_{K_{A}}>0$ while the sign of $\phi^{\prime}$ is a priori unclear. The last line used the definition of the tax bases which entails $\phi^{\prime}\left(K_{A}\right)=\partial \Phi / \partial K_{A}$.

\section{Example for Section 4.1}

Suppose that the firm's revenues from country $i$ are $R\left(K_{i}\right)=\beta K_{i}\left(A-K_{i}\right)$ while its costs are $C\left(K_{i}\right)=0.5 K^{2}$ (with $A, \beta>0$ as parameters). Profits are $R\left(K_{i}\right)-C\left(K_{i}\right)$, and taxable profits are assumed to be $\phi\left(K_{i}\right)=R\left(K_{i}\right)-\gamma C\left(K_{i}\right)$. Via the FOC (see (4)),

$$
(1-t)\left[R^{\prime}\left(K_{i}\right)-\gamma C^{\prime}\left(K_{i}\right)\right]=(1-\gamma) C^{\prime}\left(K_{i}\right)
$$

the optimal investment level with a FA system in a situation that has $t_{A}=t_{B}=t$ can be calculated as

$$
K(t)=\frac{\beta A(1-t)}{2 \beta(1-t)+1-\gamma t}
$$

Observe from (15) that $R^{\prime}-\gamma C^{\prime}<0$ iff $\gamma>1$. The RHS of (13) will, thus, be violated if $(R-\alpha C) / K<\alpha C^{\prime}-R^{\prime}=C^{\prime}(1-\gamma) /(1-t)$ or, equivalently, if

$$
K(t)>\frac{\beta A}{0.5 \gamma+\beta-(1-\gamma) /(1-t)}
$$

Combine with (16) to see that this will always be the case when:

$$
t^{2}+\frac{t}{\beta}\left(\beta-\frac{1}{2}-\frac{\gamma}{4}\right)>\frac{1}{\beta}\left(\frac{3}{4} \gamma-1\right)
$$


Choose, e.g., $\gamma=4 / 3$ and $\beta>5 / 6$ and this condition will hold for all $t \in(0,1]$. Hence, even without knowledge of the precise value of $t^{N}$, the Nash-equilibrium tax rate of tax competition under property-share apportionment is inefficiently high.

\section{References}

Anand, Bharat, and Richard Sansing, 2000. The Weighting Game: Formula Apportionment as an Instrument of Public Policy. National Tax Journal 53, 183-199.

Devereux, Michael P., 2004, Debating Proposed Reforms of the Taxation of Corporate Income in the European Union. International Tax and Public Finance 11, 71-89.

European Commission, 2006, Implementing the Community Lisbon Programme: Progress to Date and Next Steps Towards a Common Consolidated Corporate Tax Base. $\operatorname{COM}(2006) 157$ final: Brussels.

European Commission, 2003, An Internal Market without Company Tax Obstacles. Achievements, Ongoing Initiatives and Remaining Challenges. COM(2003)726final: Brussels.

European Commission, 2001, Company Taxation in the Internal Market. $\operatorname{COM}(2001)$ 582final: Brussels.

Hellerstein, Walter, and Charles E. McLure, 2004, The European Commission's Report on Company Income Taxation: What the EU Can Learn from the Experience of the US States. International Tax and Public Finance 11, 199-220.

Mintz, Jack, 2004, Corporate Tax Harmonization in Europe: It's All About Compliance. International Tax and Public Finance 11, 221-234.

Nielsen, Søren Bo, Pascalis Raimondos-Møller, and Guttorm Schjelderup, 2004, Company Taxation and Tax Spillovers: Separate Accounting versus Formula Apportionment. Mimeo, Department of Economics, Copenhagen Business School. 
Pethig, Rüdiger, and Andreas Wagener, 2007, Profit Tax Competition and Formula Apportionment. Forthcoming, International Tax and Public Finance.

Sørensen, Peter Birch, 2004, Company Tax Reform in the European Union. International Tax and Public Finance 11, 91-115.

Sørensen, Peter Birch, 2003, Company Tax Reform in the European Union. EPRU Working Paper 2003-08, Institute of Economics, Copenhagen [discussion paper version of Sørensen (2004)].

Weiner, Joann Martens, 2006, Company Tax Reform in the European Union: Guidance from the United States and Canada on Implementing Formulary Apportionment in the $E U$. Springer: New York etc.

Wellisch, Dietmar, 2004, Taxation under Formula Apportionment — Tax Competition, Tax Incidence, and the Choice of Apportionment Factors. Finanzarchiv 60, 24-41.

Wellisch, Dietmar, 2002, Corporate Income Taxation of Multinational Firms and Capital Mobility: Separate Accounting and Formula Apportionment in Comparison. Mimeo, University of Magdeburg. 


\section{CESifo Working Paper Series}

for full list see www.cesifo-group.org/wp

(address: Poschingerstr. 5, 81679 Munich, Germany, office@cesifo.de)

2032 Øystein Foros, Hans Jarle Kind and Greg Shaffer, Resale Price Maintenance and Restrictions on Dominant Firm and Industry-Wide Adoption, June 2007

2033 Jan K. Brueckner and Kurt Van Dender, Atomistic Congestion Tolls at Concentrated Airports? Seeking a Unified View in the Internalization Debate, June 2007

2034 Viet Do and Ngo Van Long, International Outsourcing under Monopolistic Competition: Winners and Losers, June 2007

2035 Nadia Fiorino and Roberto Ricciuti, Determinants of Direct Democracy, June 2007

2036 Burkhard Heer and Alfred Maussner, Inflation and Output Dynamics in a Model with Labor Market Search and Capital Accumulation, June 2007

2037 Konstantinos Angelopoulos, Jim Malley and Apostolis Philippopoulos, Public Education Expenditure, Growth and Welfare, June 2007

2038 Maarten Bosker, Steven Brakman, Harry Garretsen and Marc Schramm, Adding Geography to the New Economic Geography, June 2007

2039 Steffen Henzel, Oliver Hülsewig, Eric Mayer and Timo Wollmershäuser, The Price Puzzle Revisited: Can the Cost Channel Explain a Rise in Inflation after a Monetary Policy Shock?, July 2007

2040 Rosario Crinò, Service Offshoring and White-Collar Employment, July 2007

2041 Carsten Hefeker and Michael Neugart, Labor Market Regulation and the Legal System, July 2007

2042 Bart Cockx and Muriel Dejemeppe, Is the Notification of Monitoring a Threat to the Unemployed? A Regression Discontinuity Approach, July 2007

2043 Alfons J. Weichenrieder, Profit Shifting in the EU: Evidence from Germany, July 2007

2044 Annika Alexius and Bertil Holmlund, Monetary Policy and Swedish Unemployment Fluctuations, July 2007

2045 Axel Dreher, Jan-Egbert Sturm and Jakob de Haan, Does High Inflation Cause Central Bankers to Lose their Job? Evidence Based on a New Data Set, July 2007

2046 Guglielmo Maria Caporale and Luis A. Gil-Alana, Long Run and Cyclical Dynamics in the US Stock Market, July 2007

2047 Alessandro Balestrino, It is a Theft but not a Crime, July 2007 
2048 Daniel Becker and Michael Rauscher, Fiscal Competition in Space and Time: An Endogenous-Growth Approach, July 2007

2049 Yannis M. Ioannides, Henry G. Overman, Esteban Rossi-Hansberg and Kurt Schmidheiny, The Effect of Information and Communication Technologies on Urban Structure, July 2007

2050 Hans-Werner Sinn, Please Bring me the New York Times - On the European Roots of Richard Abel Musgrave, July 2007

2051 Gunther Schnabl and Christian Danne, A Role Model for China? Exchange Rate Flexibility and Monetary Policy in Japan, July 2007

2052 Joseph Plasmans, Jorge Fornero and Tomasz Michalak, A Microfounded Sectoral Model for Open Economies, July 2007

2053 Vesa Kanniainen and Panu Poutvaara, Imperfect Transmission of Tacit Knowledge and other Barriers to Entrepreneurship, July 2007

2054 Marko Koethenbuerger, Federal Tax-Transfer Policy and Intergovernmental PreCommitment, July 2007

2055 Hendrik Jürges and Kerstin Schneider, What Can Go Wrong Will Go Wrong: Birthday Effects and Early Tracking in the German School System, July 2007

2056 Bahram Pesaran and M. Hashem Pesaran, Modelling Volatilities and Conditional Correlations in Futures Markets with a Multivariate t Distribution, July 2007

2057 Walter H. Fisher and Christian Keuschnigg, Pension Reform and Labor Market Incentives, July 2007

2058 Martin Altemeyer-Bartscher, Dirk T. G. Rübbelke and Eytan Sheshinski, Policies to Internalize Reciprocal International Spillovers, July 2007

2059 Kurt R. Brekke, Astrid L. Grasdal and Tor Helge Holmås, Regulation and Pricing of Pharmaceuticals: Reference Pricing or Price Cap Regulation?, July 2007

2060 Tigran Poghosyan and Jakob de Haan, Interest Rate Linkages in EMU Countries: A Rolling Threshold Vector Error-Correction Approach, July 2007

2061 Robert Dur and Klaas Staal, Local Public Good Provision, Municipal Consolidation, and National Transfers, July 2007

2062 Helge Berger and Anika Holler, What Determines Fiscal Policy? Evidence from German States, July 2007

2063 Ernesto Reuben and Arno Riedl, Public Goods Provision and Sanctioning in Privileged Groups, July 2007 
2064 Jan Hanousek, Dana Hajkova and Randall K. Filer, A Rise by Any Other Name? Sensitivity of Growth Regressions to Data Source, July 2007

2065 Yin-Wong Cheung and Xing Wang Qian, Hoarding of International Reserves: Mrs Machlup’s Wardrobe and the Joneses, July 2007

2066 Sheilagh Ogilvie, 'Whatever Is, Is Right'?, Economic Institutions in Pre-Industrial Europe (Tawney Lecture 2006), August 2007

2067 Floriana Cerniglia and Laura Pagani, The European Union and the Member States: Which Level of Government Should Do what? An Empirical Analysis of Europeans' Preferences, August 2007

2068 Alessandro Balestrino and Cinzia Ciardi, Social Norms, Cognitive Dissonance and the Timing of Marriage, August 2007

2069 Massimo Bordignon, Exit and Voice. Yardstick versus Fiscal Competition across Governments, August 2007

2070 Emily Blanchard and Gerald Willmann, Political Stasis or Protectionist Rut? Policy Mechanisms for Trade Reform in a Democracy, August 2007

2071 Maarten Bosker and Harry Garretsen, Trade Costs, Market Access and Economic Geography: Why the Empirical Specification of Trade Costs Matters, August 2007

2072 Marco Runkel and Guttorm Schjelderup, The Choice of Apportionment Factors under Formula Apportionment, August 2007

2073 Jay Pil Choi, Tying in Two-Sided Markets with Multi-Homing, August 2007

2074 Marcella Nicolini, Institutions and Offshoring Decision, August 2007

2075 Rainer Niemann, The Impact of Tax Uncertainty on Irreversible Investment, August 2007

2076 Nikitas Konstantinidis, Gradualism and Uncertainty in International Union Formation, August 2007

2077 Maria Bas and Ivan Ledezma, Market Access and the Evolution of within Plant Productivity in Chile, August 2007

2078 Friedrich Breyer and Stefan Hupfeld, On the Fairness of Early Retirement Provisions, August 2007

2079 Scott Alan Carson, Black and White Labor Market Outcomes in the $19^{\text {th }}$ Century American South, August 2007

2080 Christian Bauer, Paul De Grauwe and Stefan Reitz, Exchange Rates Dynamics in a Target Zone - A Heterogeneous Expectations Approach, August 2007 
2081 Ana Rute Cardoso, Miguel Portela, Carla Sá and Fernando Alexandre, Demand for Higher Education Programs: The Impact of the Bologna Process, August 2007

2082 Christian Hopp and Axel Dreher, Do Differences in Institutional and Legal Environments Explain Cross-Country Variations in IPO Underpricing?, August 2007

2083 Hans-Werner Sinn, Pareto Optimality in the Extraction of Fossil Fuels and the Greenhouse Effect: A Note, August 2007

2084 Robert Fenge, Maximilian von Ehrlich and Matthias Wrede, Fiscal Competition, Convergence and Agglomeration, August 2007

2085 Volker Nitsch, Die Another Day: Duration in German Import Trade, August 2007

2086 Kam Ki Tang and Jie Zhang, Morbidity, Mortality, Health Expenditures and Annuitization, August 2007

2087 Hans-Werner Sinn, Public Policies against Global Warming, August 2007

2088 Arti Grover, International Outsourcing and the Supply Side Productivity Determinants, September 2007

2089 M. Alejandra Cattaneo and Stefan C. Wolter, Are the Elderly a Threat to Educational Expenditures?, September 2007

2090 Ted Bergstrom, Rod Garratt and Damien Sheehan-Connor, One Chance in a Million: Altruism and the Bone Marrow Registry, September 2007

2091 Geraldo Cerqueiro, Hans Degryse and Steven Ongena, Rules versus Discretion in Loan Rate Setting, September 2007

2092 Henrik Jacobsen Kleven, Claus Thustrup Kreiner and Emmanuel Saez, The Optimal Income Taxation of Couples as a Multi-Dimensional Screening Problem, September 2007

2093 Michael Rauber and Heinrich W. Ursprung, Life Cycle and Cohort Productivity in Economic Research: The Case of Germany, September 2007

2094 David B. Audretsch, Oliver Falck and Stephan Heblich, It's All in Marshall: The Impact of External Economies on Regional Dynamics, September 2007

2095 Michael Binder and Christian J. Offermanns, International Investment Positions and Exchange Rate Dynamics: A Dynamic Panel Analysis, September 2007

2096 Louis N. Christofides and Amy Chen Peng, Real Wage Chronologies, September 2007

2097 Martin Kolmar and Andreas Wagener, Tax Competition with Formula Apportionment: The Interaction between Tax Base and Sharing Mechanism, September 2007 